\title{
Family II pyrophosphatases from photosynthetic bacteria can hydrolyze free pyrophosphate
}

\author{
This article was published in the following Dove Press journal: \\ Research and Reports in Chemistry \\ I February 2017 \\ Number of times this article has been viewed
}

\section{Alejandra Sarmina \\ Claudia Peña-Segura \\ Heliodoro Celis}

Department of Molecular Genetics, Instituto de Fisiología Celular, Universidad Nacional Autónoma de México, Ciudad de México, México

Correspondence: Heliodoro Celis Departamento de Genética Molecular, Instituto de Fisiología Celular, Universidad Nacional Autónoma de México, Circuito Exterior s/n, Ciudad Universitaria, Coyoacán, 04510 CDMX, México

Tel +5255 56225667

Fax +525556162282

Email hcelis@ifc.unam.mx

\begin{abstract}
The hydrolytic activity from three partially purified family II pyrophosphatases from the photosynthetic bacteria Rhodobacter sphaeroides, Rhodobacter capsulatus, and Rhodovulum sulfidophilum, as well as the recombinant cytoplasmic pyrophosphatase from Rba. sphaeroides, was tested with $\mathrm{Mg}^{2+}-\mathrm{PPi}, \mathrm{Mn}^{2+}-\mathrm{PPi}$, and $\mathrm{PPi}^{4-}$. Unlike family I pyrophosphatases that hydrolyze only the $\mathrm{Mg}^{2+}-\mathrm{PPi}$ complex like those from Rhodospirillum rubrum, all family II enzymes tested showed hydrolytic activity with $\mathrm{Mg}^{2+}-\mathrm{PPi}, \mathrm{Mn}^{2+}-\mathrm{PPi}$, and $\mathrm{PPi}^{4-}$ without cation. The activity without added cation remained the same, even under exhaustive dialysis or after desalting the enzyme through a Sephadex G-25 column. However, this activity disappeared upon the addition of ethylenediaminetetraacetic acid and could not be restored by adding $\mathrm{Mg}^{2+}$. Moreover, the enzyme inactivation was not related to dissociation into lower molecular subunits as in other family II enzymes. This is the first report on pyrophosphatases that can hydrolyze pyrophosphate without a divalent cation added and that presumably contain a tightly bound divalent cation in their structure.
\end{abstract}

Keywords: cytoplasmic pyrophosphatases, metal cofactors, inorganic pyrophosphate, Rhodobacter sphaeroides, Rhodospirillum rubrum

\section{Introduction}

Soluble inorganic pyrophosphatases (EC 3.6.1.1; sPPase) are enzymes that specifically catalyze the rupture of pyrophosphate (PPi) into two molecules of orthophosphate (Pi). This reaction is essential for cell metabolism, as it provides thermodynamic pull for many biosynthetic reactions. ${ }^{1}$ Two families of sPPases (family I and family II), which are structurally different, genetically distant, ${ }^{2,3}$ and with similar catalytic mechanisms, ${ }^{4}$ have been found to date, and despite the great difference in sequence identity, both families have similar structures in the arrangement of their active site ligands and residues.

In prokaryotes, family I sPPases are homohexameric enzymes with a monomeric molecular mass of $\sim 20 \mathrm{kDa}$ and a highly conserved cuplike active site structure, formed by $14-16$ aa residues and three to four $\mathrm{Mg}^{2+}$ ions. By contrast, family II sPPases are homodimeric enzymes formed by large subunits of $\sim 34 \mathrm{kDa}$; every subunit folds into two domains in which the active site is located at the interface. In addition, all family II sPPases have the "DHH" aa signature in their active sites, similar to those of phosphoesterases. ${ }^{5}$

In order to be able to hydrolyze, both sPPase families require divalent metal cations (M) that mediate the protein-PPi interactions. ${ }^{6}$ First, divalent cations form a complex that activates the enzyme (M-E), and then, divalent cations form a complex with pyrophosphate that forms the substrate (M-PPi). In family I sPPases, $\mathrm{Mg}^{2+}$ is 
preferred as the enzyme activator in contrast to family II, in which $\mathrm{Mn}^{2+}$ is preferred over $\mathrm{Mg}^{2+}$. 7 It has been suggested that the pattern of catalysis for these enzymes is similar, ${ }^{5}$ and it consists of five steps: first, the formation of the activated complexes E-M and M-PPi; second, the binding of the substrate to the preformed enzyme-activated complex; third, isomerization of the resulting complex; fourth, breakdown of the phosphoanhydride bound by a water nucleophile, and finally, the dissociation of two Pi molecules.

Despite that enzymes from both families share the same hydrolytic pattern, their functional properties are notably different. In this article, we report that family II pyrophosphatases from the photosynthetic bacteria Rhodobacter sphaeroides, Rhodobacter capsulatus, and Rhodovulum sulfidophilum can hydrolyze substrates that do not preform an M-PPi complex, but this is not the case for the Rhodospirillum rubrum family I pyrophosphatase that needs to preform an M-PPi complex in order to hydrolyze its substrate.

\section{Materials and methods}

The chemicals used in these experiments were purchased from Sigma-Aldrich Co. and J.T. Baker. All chemicals were of analytical grade or higher.

\section{Photosynthetic bacterial cultures}

The photosynthetic strains of Rba. sphaeroides 2.4.1, Rba. capsulatus DSM 1710, Rdv. sulfidophilum DSM 1374, and Rsp. rubrum ATCC 11170 were grown anaerobically, under a tungsten lamp of $40 \mathrm{~W}$ at $30 \mathrm{~cm}$ in the medium, which was previously described by Cohen-Bazire and Kunisawa. ${ }^{8}$ Once bacterial cultures were in the late exponential phase, the cells were harvested and washed with $50 \mathrm{mM} \mathrm{3-}(\mathrm{N}-$ morpholino) propanesulfonic acid and $50 \mathrm{mM} \mathrm{KCl}, \mathrm{pH} 7.5$. Liquid medium was removed by centrifugation, and the pellet obtained (wet weight) was stored at $-80^{\circ} \mathrm{C}$.

\section{Extraction and partial purification of cytoplasmic pyrophosphatases}

Rsp. rubrum family I pyrophosphatase was partially purified as previously described by Romero et al. ${ }^{9}$ Rba. sphaeroides, Rba. capsulatus, and $R d v$. sulfidophillus family II pyrophosphatases were partially purified as reported by Celis et al. ${ }^{10}$

\section{Construction of an Escherichia coli strain that overproduces $\mathrm{His}_{6}$-sPPase from $\mathrm{Rba}$. sphaeroides}

In order to obtain the recombinant $\mathrm{His}_{6}$-sPPase from $\mathrm{Rba}$. sphaeroides, the corresponding 305 aa from the DNA region encoding the PPase was amplified by polymerase chain reaction using the following primers: Rspp Fw $5^{\prime}$ ctg aat tca tga tca agg tat tcg gcc aca 3' and Rspp Rv 5' gca agc ttt cag agc ttg agg acc gga atg 3'. The amplified region was inserted between the restriction sites EcoRI-HindIII into the pBAD/ HisB plasmid. Then, a strain of Escherichia coli Rosetta was transformed by electroporation with the mentioned plasmid. Recombinant $\mathrm{His}_{6}$-sPPase protein was overproduced as described by Suaste-Olmos et al. ${ }^{11}$

\section{Purification of $\mathrm{His}_{6}$-sPPase}

The transformed Rosetta/pFSO/pPIRL strain was grown in an Luria-Bertani broth (LB) LB medium with antibiotics (100 $\mu \mathrm{g}$ ampicillin $\cdot \mathrm{mL}^{-1}$ and $25 \mu \mathrm{g}$ chloramphenicol $\cdot \mathrm{mL}^{-1}$ ) at $37^{\circ} \mathrm{C}$ until the bacterial culture reached an $\mathrm{OD}_{600}$ of 0.6 . Then, arabinose was added at $0.2 \% \mathrm{v} / \mathrm{v}$ final concentration. After 3 hours of incubation $\left(37^{\circ} \mathrm{C}\right.$ and shaken at $\left.250 \mathrm{rpm}\right)$, the cells were centrifuged at $5,524 \times g$ for $15 \mathrm{~min}$, and the resulting pellet was resuspended in $50 \mathrm{mM}$ Tris $-\mathrm{HCl}(\mathrm{pH}$ 8.6), $10 \mathrm{mM} \mathrm{MgCl}_{2}$ (buffer A), and $10 \mathrm{mM}$ imidazole. Later, the cells were lysed with $200 \mu \mathrm{g}$ lysozyme $\mathrm{mL}^{-1}$ for $30 \mathrm{~min}$ and were disrupted by sonication (Branson Sonifier 250) with an output of $40 \%$ ( $80 \mathrm{~W})$ applying five pulses of $10 \mathrm{~s}$. Then, they were centrifuged to remove cellular debris at $15,200 \times g$ for $20 \mathrm{~min}$. The supernatant fraction was mixed with Ni-NTA beads (Quiagen NV) and placed into a polypropylene column. Then, the mixture was washed 15 times with buffer A plus $20 \mathrm{mM}$ imidazole, and finally, the recombinant protein was eluted with buffer A plus $200 \mathrm{mM}$ of imidazole.

\section{Pyrophosphatase assay}

PPase assays were carried out at $37^{\circ} \mathrm{C}$ in a reaction medium containing $50 \mathrm{mM}$ Tris- $\mathrm{HCl}$ (pH 8.6), $2 \mathrm{mM} \mathrm{Na}_{4} \mathrm{PPi}$ (pH 8.6), and $3 \mathrm{mM} \mathrm{MgCl}_{2}$ (modifications of these conditions are indicated in the figure legends). The reactions were initiated by adding the enzyme and arrested by the addition of trichloroacetic acid to a final concentration of $6 \% \mathrm{v} / \mathrm{v}$. The hydrolyzed pyrophosphate was determined according to Sumner. ${ }^{12}$ Proteins were measured by the method of Lowry et al, ${ }^{13}$ using bovine serum albumin as a standard. All experiments were repeated at least three times.

\section{Native polyacrylamide gel electrophoresis} Gel electrophoresis was performed as in Laemmli, ${ }^{14}$ without sodium dodecyl sulfate and dithiothreitol; then, proteins were silver stained according to Bloom et al. ${ }^{15}$ 


\section{Results and discussion \\ Divalent-cation requirement for PPase activity}

It is well known that family II pyrophosphatases need divalent metal ions as necessary cofactors for hydrolysis, expressing their maximal hydrolytic rate with $\mathrm{Mn}^{2+}$ and $\mathrm{Mg}^{2+}$. However, the cytoplasmic family II pyrophosphatase from the photosynthetic bacterium Rba. sphaeroides (Rs-PPase) can hydrolyze substrate without the addition of divalent cations to the reaction medium (Table 1). Family I pyrophosphatases from photosynthetic bacteria like Rsp. rubrum cannot hydrolyze pyrophosphate with $\mathrm{Mn}^{2+}$, expressing their maximal hydrolytic rate with $\mathrm{Mg}^{2+}$, and they certainly cannot function if the reaction medium does not contain divalent cations. ${ }^{10}$

The amount of hydrolyzed pyrophosphate by the partially purified Rs-sPPase when divalent cations were not added

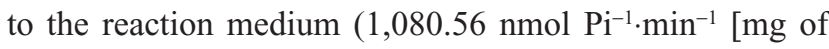
protein $]^{-1}$ ) was equivalent to the amount obtained when

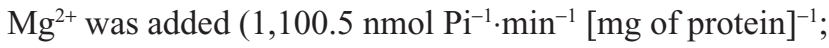
Table 1); this suggests the existence of divalent cations bound to the enzyme that may form the metal-substrate complex. Based on the above assumption, another two partially purified family II pyrophosphatases from the photosynthetic bacteria Rba. capsulatus (Rc-PPase) and Rdv. sulfidophilum (RvPPase) were depleted from free cations desalting the enzymes

Table I Specific activity of family I (Rsp. rubrum) and family II (Rba. sphaeroides, Rba. capsulatus, Rdv. sulfidophilum) PPases, with and without divalent cation added at the hydrolysis reaction medium: $50 \mathrm{mM}$ Tris- $\mathrm{HCl}(\mathrm{pH}$ 8.6), $2 \mathrm{mM} \mathrm{Na4PPi}$, and $3 \mathrm{mM}$ of divalent cation

\begin{tabular}{|c|c|c|c|}
\hline \multirow[t]{2}{*}{ Bacteria } & & \multicolumn{2}{|c|}{$\mathrm{nmol}$ Pi.min $\mathrm{m}^{-1}$ (mg of protein) $)^{-1}$} \\
\hline & & Control & $\begin{array}{l}\text { Desalted with } \\
\text { Sephadex G-25 }\end{array}$ \\
\hline \multirow[t]{3}{*}{ Rsp. rubrum } & - & 0.00 & \\
\hline & $\mathrm{MgCl}_{2}$ & 127.46 & \\
\hline & $\mathrm{MnCl}_{2}$ & 0.00 & \\
\hline Rba. & - & $\mathrm{I}, 080.56$ & $\mathrm{I}, 400.8$ \\
\hline \multirow[t]{2}{*}{ sphaeroides } & $\mathrm{MgCl}_{2}$ & $\mathrm{I}, 100.5$ & $\mathrm{I}, 002 . \mathrm{I}$ \\
\hline & $\mathrm{MnCl}_{2}$ & $\mathrm{I}, 400 . \mathrm{I}$ & $1,500.2$ \\
\hline Rba. & - & $1,320.8$ & 920.46 \\
\hline \multirow[t]{2}{*}{ capsulatus } & $\mathrm{MgCl}_{2}$ & $1,410.1$ & $\mathrm{I}, 460.0$ \\
\hline & $\mathrm{MnCl}_{2}$ & $1,010.3$ & $1,006.8$ \\
\hline$R d v$. & - & 650.22 & 390.605 \\
\hline \multirow[t]{2}{*}{ sulfidophilum } & $\mathrm{MgCl}_{2}$ & $\mathrm{I}, 403.28$ & $\mathrm{I}, 403.439$ \\
\hline & $\mathrm{MnCl}_{2}$ & $\mathrm{I}, 070.24$ & $1,003.99$ \\
\hline
\end{tabular}

Note: The symbol "-" means that no cations were added at the reaction medium. Abbreviations: Rsp. rubrum, Rhodospirillum rubrum; Rba. sphaeroides, Rhodobacter sphaeroides; Rba. capsulatus, Rhodobacter capsulatus; Rdv. sulfidophilum, Rhodovulum sulfidophilum. three times through a Sephadex G-25 filtration column. Then, the hydrolytic activities of the enzymes were tested with and without metal cofactors (Table 1). Despite the lack of externally added free divalent cations, all FII pyrophosphatases tested (Rs-PPase, Rc-PPase, and Rv-PPase) can hydrolyze pyrophosphate. Moreover, we know that if a PPi-Mg complex is not formed, the protein-PPi interactions are not being replaced by monovalent cations from the complex $\mathrm{Na}_{4} \mathrm{PPi}$; this is because the substrates $\mathrm{K}_{4} \mathrm{PPi}, \mathrm{Li}_{4} \mathrm{PPi}$, and Tris-PPi are hydrolyzed at the same rate (data not shown).

\section{Effect of ethylenediaminetetraacetic acid on the enzyme activity}

Family II pyrophosphatases were cleaned from free divalent cations after running the enzyme three times through a Sephadex G-25 column. The hydrolytic activity of these cleaned enzymes is inhibited by ethylenediaminetetraacetic acid (EDTA) at low concentrations (Figure 1). All Rs-PPase, Rc-PPase, and Rv-PPase decrease their hydrolytic activity by $50 \%$ with $5 \mu \mathrm{M}$ of EDTA, and with $100 \mu \mathrm{M}$ of EDTA, the activity is almost completely lost. To discard the possibility that even a family I pyrophosphatase hydrolytic activity using $\mathrm{Mg}^{2+}-\mathrm{PPi}$ as a substrate could be inhibited by small concentrations of EDTA, the Rsp. rubrum family I pyrophosphatase (Rr-PPase) was tested with increasing concentrations of EDTA. The enzyme was not inhibited even with a fivefold concentration to the one needed for the complete inhibition of the family II desalted enzyme. Owing to the hydrolytic activity without an added cation had not changed the three

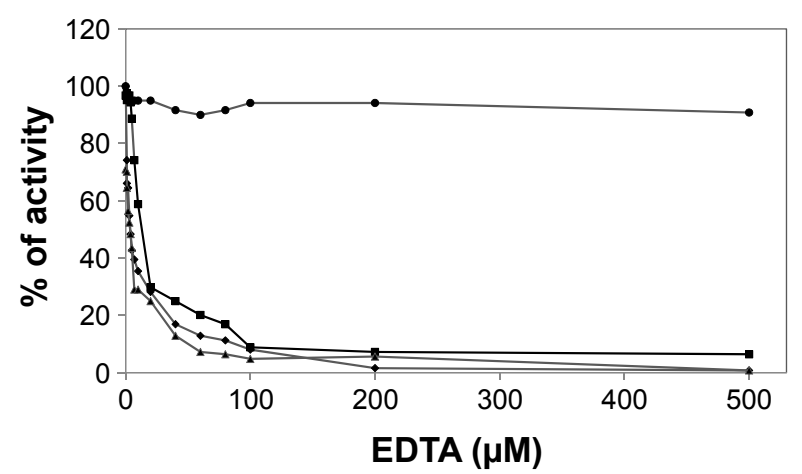

Figure I EDTA effect on the hydrolysis of pyrophosphatase.

Notes: Reaction conditions were $50 \mathrm{mM}$ Tris- $\mathrm{HCl}(\mathrm{pH} \mathrm{8.6)}$ and EDTA at the concentrations indicated on the abscissa. Different complexes were used as substrates: $\mathrm{Mg}-\mathrm{PPi}\left(3 \mathrm{mM} \mathrm{MgCl}\right.$ and $2 \mathrm{mM} \mathrm{Na}_{4} \mathrm{PPi}$ ) in Rsp. rubrum (•) family I sPPase and PPi $2 \mathrm{mM}$ without divalent cation added in Rba. capsulatus ( $\mathbf{\square})$, Rba. sphaeroides $(\diamond)$, and $R d v$. sulfidophilum ( $\Delta$ ) family II sPPases. For family I pyrophosphatase, $100 \%$ is equivalent to $127 \mathrm{nmol} \mathrm{Pi} \cdot \mathrm{min}^{-1}$ (mg of protein)-1, and for family II pyrophosphatases, $100 \%$ is equivalent to $1,240 \mathrm{nmol} \mathrm{Pi} \cdot \mathrm{min}^{-1}$ ( $\mathrm{mg}$ of protein $)^{-1}$.

Abbreviations: EDTA, ethylenediaminetetraacetic acid; Rsp. rubrum, Rhodospirillum rubrum; Rba. capsulatus, Rhodobacter capsulatus; Rba. sphaeroides, Rhodobacter sphaeroides; Rdv. sulfidophilum, Rhodovulum sulfidophilum. 
times dialyzed and desalted enzyme $\left(1,110 \mathrm{nmol} \mathrm{Pi} \cdot \mathrm{min}^{-1}[\mathrm{mg}\right.$ protein $]^{-1}$ at the beginning to $950 \mathrm{nmol} \mathrm{Pi} \cdot \mathrm{min}^{-1}[\mathrm{mg} \text { protein }]^{-1}$ in the end) in which we calculated that only $1.2 \times 10^{-18} \mathrm{M}$ of $\mathrm{Mg}^{2+}$ remains; it is possible that inhibition by EDTA is caused by chelation of a tightly bound divalent cation, available from the enzyme structure (not the media), that serves as a cofactor for the enzyme or as a part of the substrate inside the active site. To know whether the cation may reassociate with the enzyme under further dialysis of the chelate, the recombinant Rba. sphaeroides (rRs-PPase) was treated with EDTA and subsequently dialyzed. It is worth noting that once inhibited, the rRs-PPase by the chelate, the hydrolytic activity cannot be restored either by EDTA dialysis or by adding $\mathrm{Mg}^{2+}$ (Figure 2). In this case, the irreversible loss of activity may lay in the fact that in some reports of family II pyrophosphatases such as Basillus subtillis, Streptococcus gordonii, and Streptococcus mutans, in the absence of metal ions ( $2 \mathrm{mM}$ EDTA present), the sedimentation velocity of the enzymes decreased markedly, indicating dissociation into lower molecular mass species. ${ }^{16}$

However, regardless of the amount of EDTA added at the recombinant Rba. sphaeroides family II pyrophosphatase, the dissociation into lower molecular mass subunits does not occur (Figure 3), as judged by the native electrophoresis, suggesting that the quaternary integrity of the enzyme is maintained even after inactivation with EDTA and cation unavailability.

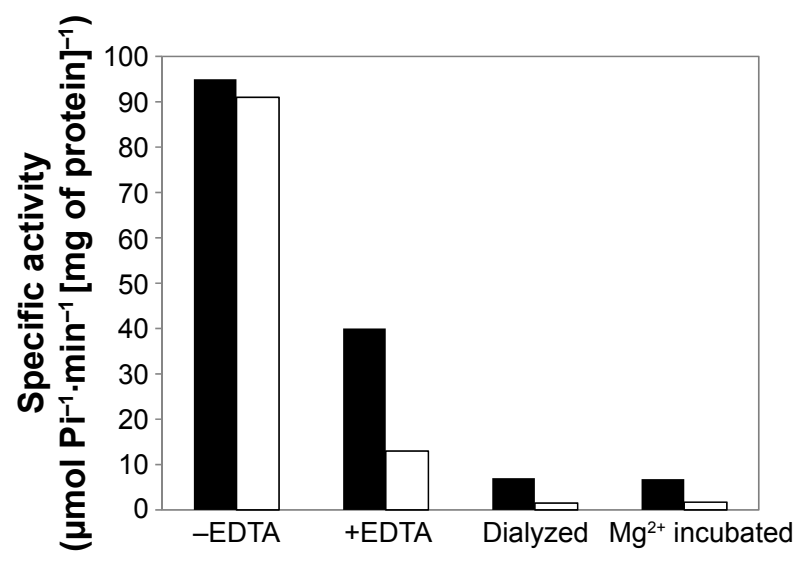

Figure 2 EDTA effect on the Rba. sphaeroides recombinant sPPiase activity. Notes: Black bars represent reactions with $3 \mathrm{mM} \mathrm{MgCl}$ added, and white bars represent reactions in which no divalent cation was added. -EDTA represents hydrolysis reaction without EDTA. +EDTA represents hydrolysis reaction with $100 \mathrm{mM}$ EDTA-preincubated enzyme for $15 \mathrm{~min}$ at room temperature. Dialyzed represents EDTA-preincubated enzyme dialyzed against $20 \mathrm{mM}$ Tris- $\mathrm{HCl}, \mathrm{pH}$ 8.6, and $0.1 \mathrm{mM} \mathrm{CoCl}$. $\mathrm{Mg}^{2+}$ incubated represents dialyzed enzyme, incubated with $7 \mathrm{mM} \mathrm{MgCl}$ for 7 days at $8^{\circ} \mathrm{C}$. Reaction conditions were $50 \mathrm{mM}$ Tris- $\mathrm{HCl}(\mathrm{pH} \mathrm{8.6)}$, $2 \mathrm{mM} \mathrm{Na} 4 \mathrm{PPi}$, and EDTA. Reaction incubation temperature was $37^{\circ} \mathrm{C}$.

Abbreviations: EDTA, ethylenediaminetetraacetic acid; Rba. sphaeroides, Rhodobacter sphaeroides.

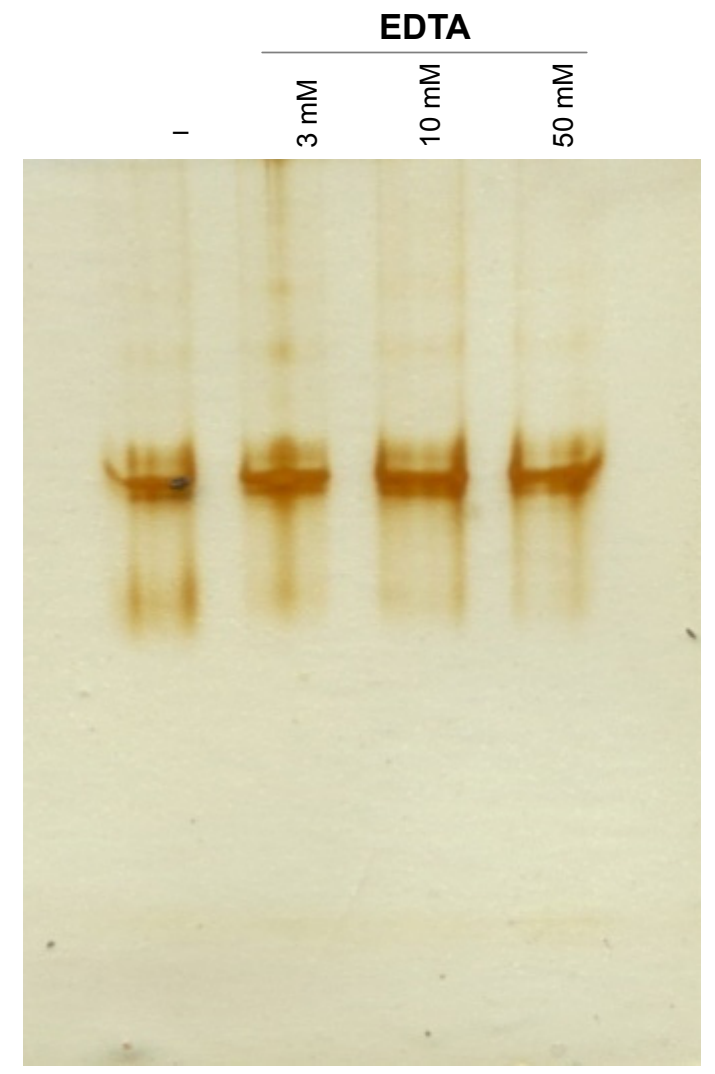

Figure 3 Silver-stained native PAGE of the recombinant Rba. sphaeroides sPPase preincubated with different concentrations of EDTA.

Abbreviations: PAGE, polyacrylamide gel electrophoresis; Rba. sphaeroides, Rhodobacter sphaeroides; EDTA, ethylenediaminetetraacetic acid.

Finally, it is well known that EDTA chelates divalent cation and its use in reports in which the role of divalent cations is discussed are plenty. Since the first characterization of a family II enzyme from B. subtillis ${ }^{17}$ was stated that EDTA causes disruption of subunits and subsequently loss of activity, this is the case for another two family II pyrophosphatases mentioned earlier, S. gordonii and S. mutans, that shows the same behavior as B. subtillis, including the fact that inhibition caused by EDTA can be reverted.

We do not have detailed mechanistic explanation about how the pyrophosphate is hydrolyzed without added divalent cations, why the quaternary structure of our enzyme is maintained in the presence of EDTA or why the loss of activity cannot be restored even with exhaustive dialysis and divalent cation supplied. Only solving the crystal structures of these enzymes with and without divalent cations may reveal if they can hydrolyze free pyrophosphate using a structural tightly bound cation that shields the charge from this highly electronegative molecule. What we already know is that another structural cation is also present in the photosynthetic bacterium family II pyrophosphatase from Rba. capsulatus ${ }^{18}$ 
proton-induced X-ray emission analysis showed that three $\mathrm{Co}^{2+}$ ions are coupled in the enzyme, but no localization in the structure is determined. We think, based on non-published data, that $\mathrm{Co}^{2+}$ plays a protective role against chelation with EDTA, and this is why we are currently working on solving the crystal structures from this enzyme.

\section{Conclusion}

Although the structure of family II pyrophosphatases differs greatly from that of family I, yet they catalyze the same hydrolysis reaction with apparently the same mechanism. However, unlike family I PPases, the Rba. sphaeroides family II PPase, as well as other photosynthetic bacterium pyrophosphatases belonging to the same family, can hydrolyze PPi presumably with a tightly bound divalent cation in its structure, without preforming a PPi-divalent cation substrate complex.

Apparently, the tightly bound divalent cation from $R b a$. sphaeroides family II PPases is not related to the enzyme quaternary structure stability, since its dissociation into lower molecular subunits was not observed in the presence of EDTA, as in other non-photosynthetic bacterium family II pyrophosphatases.

\section{Acknowledgments}

This work was supported by the IFC Molecular Genetics Department's budget. We thank the Molecular Biology Unit of the IFC for sequencing facilities and for performing primer synthesis. We thank Diego Gonzalez Halphen and Miriam Vazquez Acevedo for their support with reagents and helpful advice and Fernando Suaste Olmos and José de Jesús García Trejo for their excellent technical help.

\section{Disclosure}

The authors report no conflicts of interest in this work.

\section{References}

1. Kornberg A. The participation of inorganic pyrophosphate in the reversible enzymatic synthesis of diphosphopyridine nucleotide. J Biol Chem. 1948;176(3):1475-1476.
2. Shintani T, Uchiumi T, Yonezawa T, et al. Cloning and expression of a unique inorganic pyrophosphatase from Bacillus subtilis: evidence for a new family of enzymes. FEBS Lett. 1998;439(3):263-266.

3. Young TW, Kuhn NJ, Wadeson A, Ward S, Burges D, Cooke GD. Bacillus subtilis ORF yybQ encodes a manganese-dependent inorganic pyrophosphatase with distinctive properties: the first of a new class of soluble pyrophosphatase? Microbiology. 1998;144(pt 9):2563-2571.

4. Heikinheimo P, Lehtonen J, Baykov A, Lahti R, Cooperman BS, Goldman A. The structural basis for pyrophosphatase catalysis. Structure. 1996;4(12):1491-1508.

5. Merckel MC, Fabrichniy IP, Salminen A, et al. Crystal structure of Streptococcus mutans pyrophosphatase: a new fold for an old mechanism. Structure. 2001;9(4):289-297.

6. Heikinheimo P, Tuominen V, Ahonen AK, et al. Toward a quantummechanical description of metal-assisted phosphoryl transfer in pyrophosphatases. Proc Natl Acad Sci U S A. 2001;98(6):3121-3126.

7. Fabrichniy IP, Lehtio L, Tammenkoski M, et al. A trimetal site and substrate distortion in a family II inorganic pyrophosphatase. $J$ Biol Chem. 2007;282(2):1422-1431.

8. Cohen-Bazire G, Kunisawa R. Some observations on the synthesis and function of the photosynthetic apparatus in Rhodospirillum rubrum. Proc Natl Acad Sci U S A. 1960;46(12):1543-1553.

9. Romero I, García-Contreras R, Celis H. Rhodospirillum rubrum has a family I pyrophosphatase: purification, cloning, and sequencing. Arch Microbiol. 2003;179(5):377-380.

10. Celis H, Franco B, Escobedo S, Romero I. Rhodobacter sphaeroides has a family II pyrophosphatase: comparison with other species of photosynthetic bacteria. Arc Microbiol. 2003;179(5):368-376.

11. Suaste-Olmos F, Domenzian C, Mireles-Rodríguez JC, et al. The flagellar protein FliL is essential for swimming in Rhodobacter sphaeroides. J Bacteriol. 2010;23(23):6230-6239.

12. Sumner JB. A method for the collorimetric determination of phosphorous. Science. 1944;100(2601):413-415.

13. Lowry ON, Rosenbrough J, Farr AL, et al. Protein measurement with the follin phenol reagent. $J$ Biol Chem. 1951;254:6528-6537.

14. Laemmli UK. Cleavage of structural proteins during the assembly of the head of bacteriophage T4. Nature. 1970;227(5259):680-685.

15. Bloom H, Beier H, Gross HS. Improved silver staining of plant proteins, RNA and DNA in polyacrylamide gels. Electrophoresis. 1987;8:93-99.

16. Parfenyev AN, Salminen A, Halonen P, Hachimori A, Baykov AA, Lahti R. Quaternary structure and metal ion requirement of family II pyrophosphatases from Bacillus subtilis, Streptococcus gordonii, and Streptococcus mutans. J Biol Chem. 2001;276(27):24514-24518.

17. Kuhn NJ, Ward S. Purification, properties, and multiple forms of a manganese-activated inorganic pyrophosphatase from Bacillus subtilis. Arch Biochem Biophys. 1998;354(1):47-56.

18. Solís C, Celis H, Romero I, et al. Metal/protein ratio determination in the Rhodobacter capsulatus cytoplasmic pyrophosphatase enzyme by particle induced X-ray emission. J Microbiol Methods. 2011;84(2): $272-277$.

\section{Publish your work in this journal}

Research and Reports in Chemistry is an international, peer reviewed, open access journal publishing original research, reports, reviews and commentaries on all areas of chemistry. The manuscript management

\section{Dovepress}

system is completely online and includes a very quick and fair peer review system, which is all easy to use. Visit http://www.dovepress.com/ testimonials.php to read real quotes from published authors. 